EKAIA (2022), artikulua prentsan/article in press. https://doi.org/10.1387/ekaia.23255

Behin-behineko bertsioa (euskara-orrazketaren faltan).
ISSN: 0214-9001 e-ISSN: 2444-3255

CUPV/EHU Press

\title{
Zer dela eta zahartzen gara?
}

(Why we age)

\author{
Leire Moreno-Cugnon ${ }^{1 *}$, Miren Revuelta ${ }^{2}$, Ander Matheu ${ }^{3,4,5}$ \\ ${ }^{1}$ Kantzer zelulen seinalizazio eta metabolismoaren laborategia, Biozientzietan ikerketa \\ kooperatiboa (CIC bioGUNE) \\ ${ }^{2}$ Fisiologia departamentua, Medikuntza eta Odontologia fakultatea (UPV/EHU) \\ ${ }^{3}$ Onkologia departamentua, Biodonostia ikerketa zentroa \\ ${ }^{4}$ IKERBASQUE, Basque Foundation for Science \\ ${ }^{5}$ CIBER of Frailty and Healthy Aging (CIBERfes), Carlos III Institutua
}

\begin{abstract}
LABURPENA: Zahartzea izaki bizidun guztietan gertatzen den prozesu natural bat da, denbora igarotzearen ondoriozko gainbehera funtzional bezala defini daitekeena. Gaur egun, hainbat hipotesi proposatu dira zahartzearen zergatia azaltzeko, eta horien artean zelula amen agortzearen ikerketa lerroa aurkitzen da. Zelula amak, berritze gaitasuna izateaz gain, ondoren zelula diferentziatuak sortzeko gai dira, zahartzaroarekin kopuruz murriztuz doazelarik. Zehazki, zahartzaroak fisiologikoki gehien kaltetzen duen organoa garuna da, eta adinak eragindako garuneko zelula amen agortze honek neuronen berritzea zailtzen du, indibiduo helduetan ikus dezakegun gainbehera kognitiboa eraginez. Neurogenesia garuneko eremu espezifikoetan gertatzen da, bentrikulu azpiko eremuan eta hipokanpoko granulu azpiko eremuan, eta azken ikerketen arabera bai haurtzaroan zein zahartzaroan gertatzen den prozesu bat da. Beraz, zahartzaroan zehar zelula ama hauen funtzioa nola mantendu daitekeen ikertzea oso garrantzitsua da, alderdi kognitiboan emandako galerak ekiditeko.
\end{abstract}

HITZ GAKOAK: Zahartzaroa, neurogenesia, garuneko zelula amak.

ABSTRACT: Aging is a natural human process that produce functional impairment. There are many hypothesis that argue human aging, such as the exhaustion of stem cells. Stem cells have renewal and differentiation capacity and the number of these cells is decreased with aging. Brain is one of the most affected organ during aging. The decrease of Neural Stem Cell (NSC) reduce neuronal regeneration provoking cognitive decline. Neurogenesis occur in specific niches of the brain: the subventricular zone and the dentate gyrus of the hippocampus. Recent studies have demonstrated that this neurogenesis occur not only in the childhood but also during aging, resulting really important to investigate how to maintain neural stem cell function during aging to reduce cognitive outcomes.

KEYWORDS: Aging, neurogenesis, Neural Stem Cells.

1

*Harremanetan jartzeko/ Corresponding author: Miren Revuelta, Fisiologia saila, Medikuntza eta Erizaintza Fakultatea (UPV/EHU), Leioa. ํㅡ. https://orcid.org/0000-0001-8126-2050,miren.revuelta@ehu.eus

Nola aipatu / How to cite: 1 Moreno-Curgnon, Leire; 2. Revuelta, Miren; 3 Matheu, Ander (2022). $<<$ Zer dela eta zahartzen gara? >>, Ekaia,. (https://doi.org/10.1387/ekaia.23255)

Jasoa: abenduak 9, 2021; Onartua: urtarrilak 31, 2022

ISSN 0214-9001-eISSN 2444-3225 / @ 2022 UPV/EHU

(C) (1) (\$) (1)

BY NC SA Obra Creative Commons Atribución 4.0 Internacional-en lizentziapean dago 


\section{Sarrera}

Zahartzea izaki bizidun guztietan gertatzen den prozesu natural bat da, denbora igarotzearen ondoriozko gainbehera funtzional bezala defini daitekeena. Prozesu hau gorputzeko zelula eta ehun orotan pairatzen da, hauen funtzioa kaltetuz eta azkenik, indibiduoaren heriotza eraginez. Azken urteotan bizi-baldintzetan eta hezkuntzan emandako hobekuntzek, haurren heriotzatasaren murrizteak eta medikuntza arloan emandako aurrerapenek besteak beste, izugarri handitu dute mundu mailako bizi-itxaropena. Euskal Herrian zehazki, datuek argi uzten dute populazioa urtetik urtera zahartzen ari dela, soilik azken hiru hamarkadetan 65 urtetik gorako biztanleria \% 8,6-tik 22,1-ra igo delarik. Dirudienez joera hau luzaroan mantenduko da, izan ere, iragarpenek 2030erako proportzio hau \%27,6-koa izango dela diote. Era berean, 80 urtetik gorakoen biztanleria ere \%5,5-tik \%12,7-ra bikoiztuko da gizartean ${ }^{1}$ (1. irudia).

1.irudia: (a) 1950. urteko gizonezko (barra urdinez adierazita) eta emakumezkoen (barra
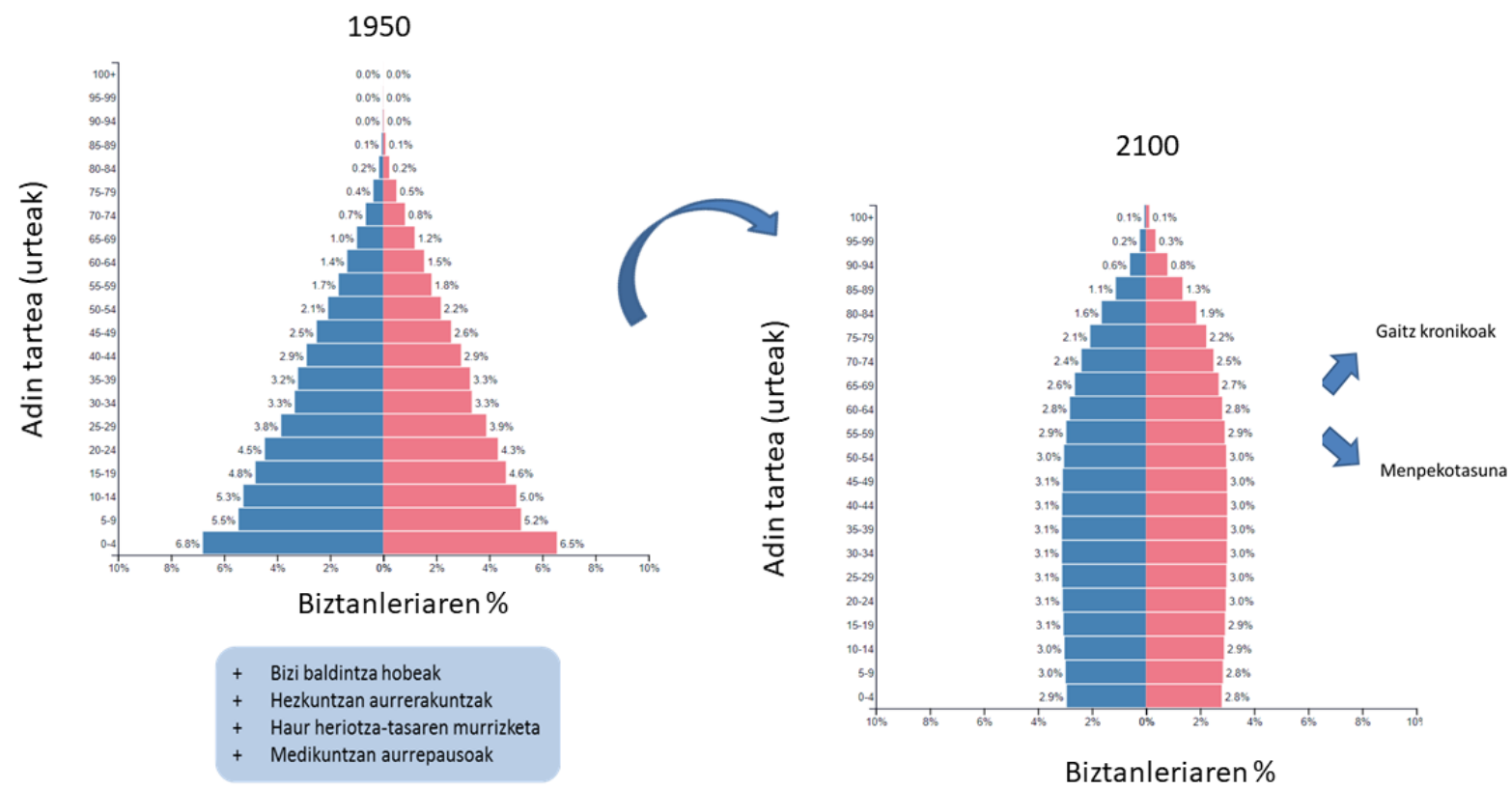

gorriez adierazita) biztanleriaren ehunekoa (\%) adin tarte ezberdinetan banatuta eta (b) 2100. urterako esperotako aldaketa. 1950. urtetik gizartean izandako hobekuntzak adierazten dira eta 2100. urterako espero ditugun ondorioak. (Arg. populationpyramid.net- web orritik moldatua) 
Aldiz, bizi-itxaropen maximoari dagokionez (118 urte), ez da aldaketa handirik izango, hurrengo 50 urteetan soilik 6 urtetako aldaketa izanik ${ }^{1}$. Estimazio hauek bat datoz inpaktu altuko zientzia aldizkarietan argitaraturiko bi lan indepedientek frogatu dutenarekin, hau da, gizakion bizi-esperantza naturalki 115 urtetara mugaturik dagoela ${ }^{1,2}$. Biologikoki urte hauek bi fasetan bana daitezkeela nabarmendu behar da, lehenengo aldi osasuntsu bat eta indibiduoak adinari loturiko gaitzak eta menpekotasuna pairatzen dituen bigarren aldi bat. Izan ere. azken hamarkadetan irabazitako bizi-itxaropenaren luzatzea estuki loturik dago menpekotasun eta gaixotasun kronikoen garatzearekin, hala nola, Alzheimerra eta Parkinson gaixotasuna bezalako gaitz neurodegeneratiboak ${ }^{2}$ (2. irudia). Beraz, gizartearen zahartzeak mundu mailako izugarrizko erronka suposatzen du eta ondorioz, azken urteotan zahartze osasuntsu bat baimendu dezaketen mekanismoak zeintzuk izan daitezkeen argitzeko interes nabarmena piztu da. Gaur egun, hainbat hipotesi proposatu dira zahartzearen zergatia azaltzeko, horien artean zelula amen agortzearen ikerketa lerroa aurkitzen delarik ${ }^{3}$.

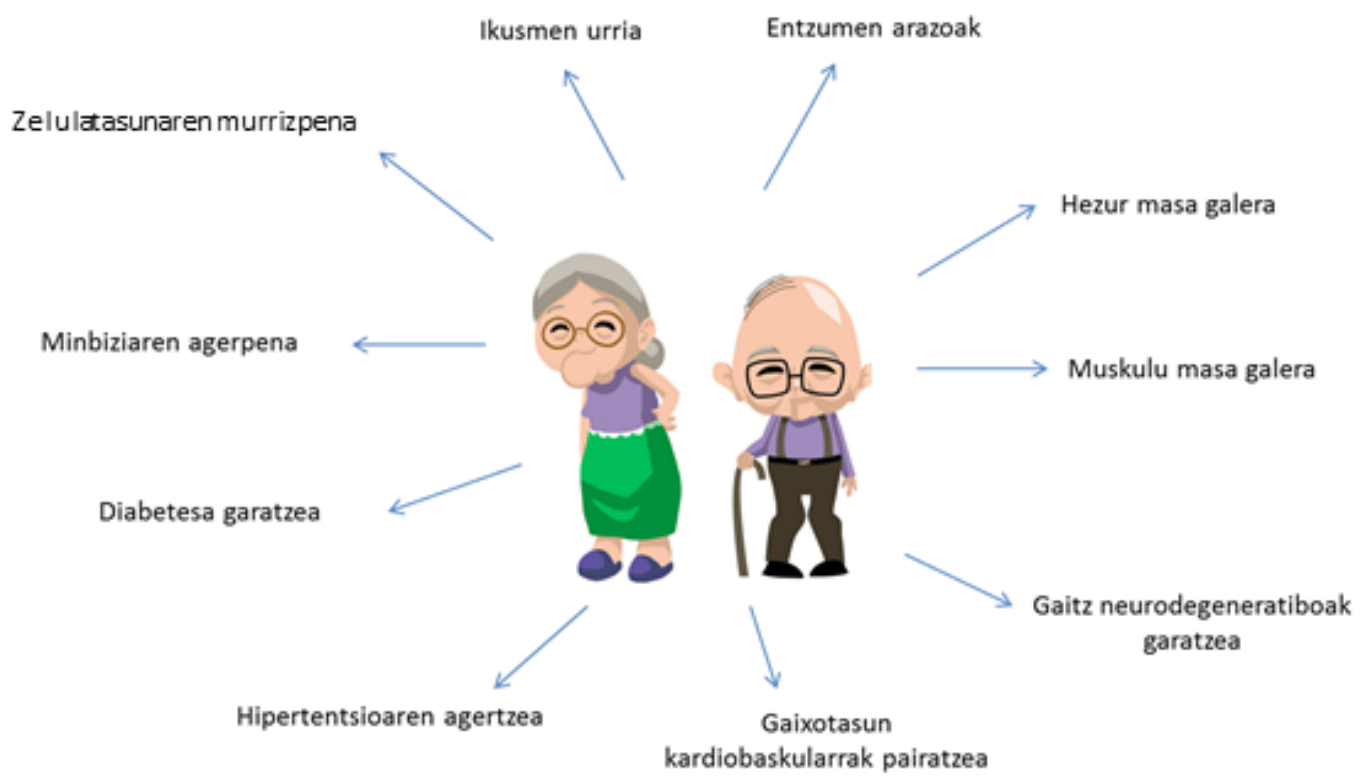

2.irudia: Zahartzaroak gizakien osasunean dituen ondorioak. Ondorio hauetatik aipagarrienak gaitz neurodegeneratiboak garatzea, minbizia eta zelulen heriotza gertatzea dira osasun sisteman duten inpaktu ekonomikoa dela eta. Arg. Egileak

\section{Zelula amen garrantzia}

Zelula amak, diferentziatu gabeko zelulak dira, berritze gaitasuna dute eta ondoren zelula diferentziatuak sortzeko gai dira. Enbrioi garaian, zelula hauek dira organismoa osatuko duten 
ehun ezberdinen sorreraren arduradunak. Garapen prozesuak aurrera egin ahala, zelula hauen gehiengoa desagertuz doa, eta helduaroan zelula ama helduak dira ehun ezberdinetako zelula mota guztietara ezberdintzeko gaitasuna duten zelula bakarrak. Zelula hauek, enbrioi-garaian ez bezala, nitxo espezializatuetan aurkitzen dira soilik, non beraien babes zein mantenurako mikroinguru egokia duten ${ }^{4}$. Egoera fisiologikoan zelula ama helduek berritze tasa txikia dute, ziklo zelularreko G0 aldian (lokarturik) mantentzen dira eta soilik estres egoera baten edo bestelako beharren aurrean aktibatzen dira. Kasu horietan, zelulak modu asimetriko batean bikoizten dira, hau da, zelula amaren berdina izango den beste zelula bat eta bigarren zelula espezializatu bat emango duen bikoizketa gertatuko da, zelulen berritzea eta diferentziazioa baimenduz hurrenez hurren ${ }^{4}$. Prozesu honi esker ehun guztien funtzionamendu egokia bermatzen da (3. irudia).

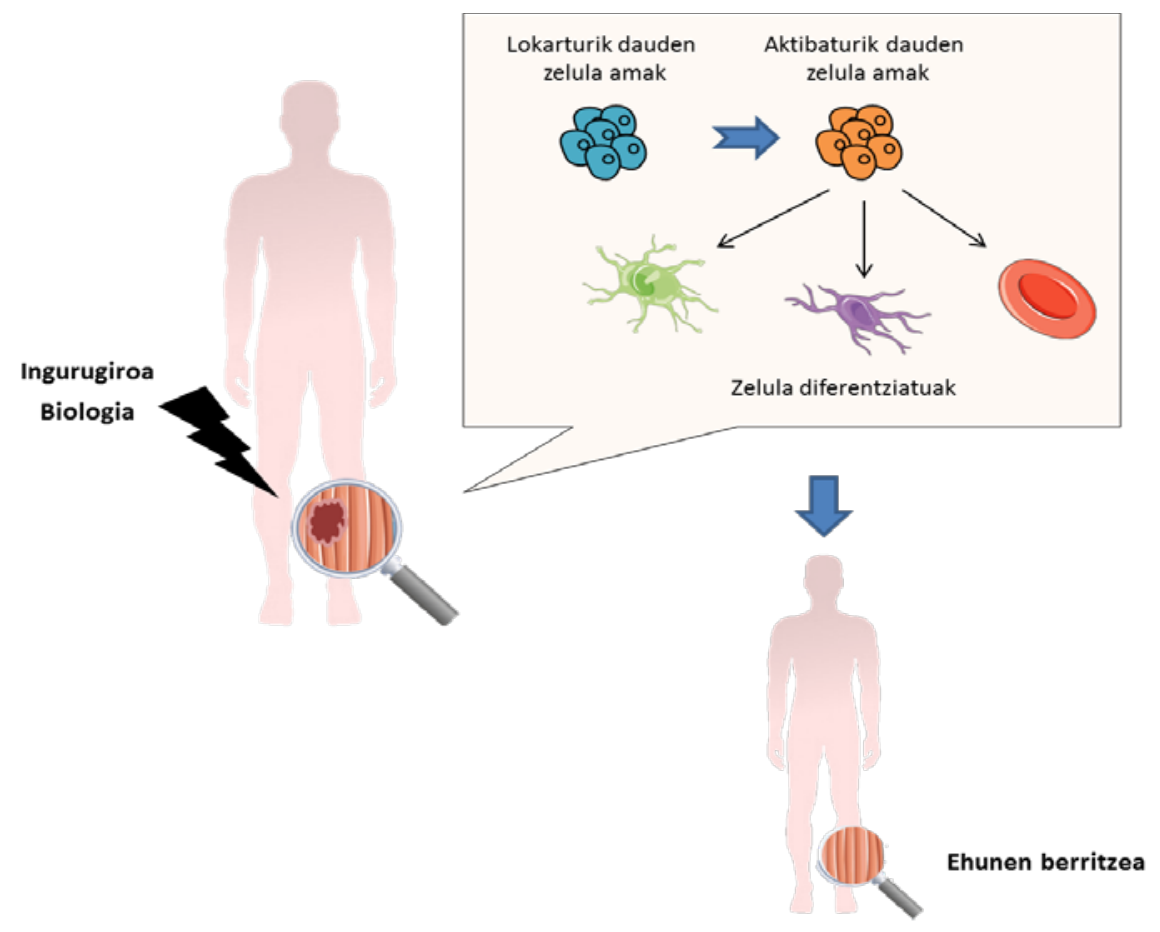

3.irudia: Estres egoera baten eraginez edo bestelako beharren aurrean lokartutik dauden zelula amak aktibatzean gertatzen den zelulen diferentziazioa. Diferentziazio honen eraginez zelula berriak sor daitezke ehun espezializatuak sortuz eta ondorioz, kaltetutako ehunak berrizta daitezke. Arg. Egileak

Zelula ama helduen aktibitatea etengabea balitz, gorputzeko zelula guztiak modu mugagabe batean ordezkatuko lirateke, organoak modu efiziente batean berriztatuz. Hala ere, zelula amen funtzioa adinarekin murriztuz doa. Ezaguna da denboraren poderioz ehun ezberdinek pairatzen duten efektua ezberdina dela, muskulu, garun edota larruazalean zelula amen kopurua murrizten 
delarik eta hesteetan zein odolean berain aktibitatea konprometiturik ikusten delarik ${ }^{4}$. Gauzak honela, zahartzaroan eragina duten faktore biologikoen artean zelula amen agorpena ezaugarri zelular garrantzitsu bat dela baieztatu da, ehunen mantentze eta birsorkuntza gaitasunean duten izugarrizko eragina dela eta (4. irudia).
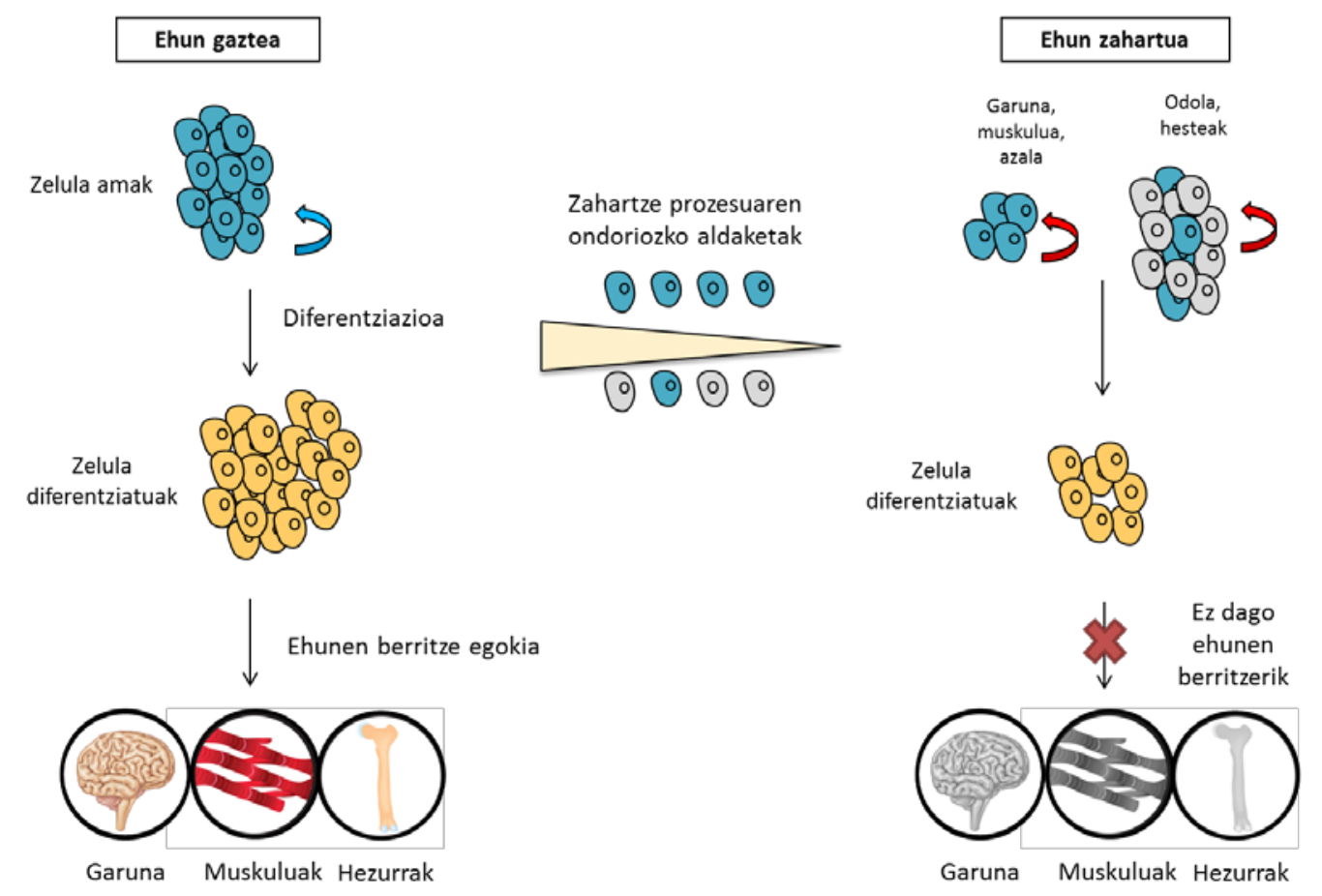

4.irudia: Zahartzaroak eragindako zelula amen gutxitzea eta honek fisiologikoki organo ezberdinetan duen eragina. Zelulen berritzea gutxitu edo deuseztatu egiten da zelula amen gutxitzearen eraginez. Argi ikusi dezakegu batez ere ehun hematopoietiko, muskulu ehunetan eta garunean ama zelula hauen gutxitzeak duen eragina. Arg. Egileak

\section{Garunaren zahartzea}

Zahartzaroak fisiologikoki gehien kaltetzen duen organoa garuna da, eta adinak eragindako garuneko zelula amen agortze honek neuronen berritzea zailtzen du, indibiduo helduetan ikus dezakegun gainbehera kognitiboa eraginez. Beraz, oso garrantzitsua da zahartzaroan zehar zelula ama hauen funtzioa nola mantendu daitekeen ikertzea alderdi kognitiboan emandako galera hauek ekiditeko.

Ikerketa hau aurrera eramateko, lehenik eta behin, ezinbestekoa da garuneko zelula amen kokapena zein den ezagutzea. Izan ere, neurogenesia, hau da, zelula ametatik neurona funtzional berrien sortze-prozesua, garuneko eremu espezifikoetan gertatzen da: bentrikulu azpiko eremuan (ingelesetik subventricular zone edo SVZ) eta hipokanpoko granulu azpiko 
eremuan (ingelesetik subgranular zone edo SGZ) hain zuzen ere. Garuneko zelula amak, erdiko nerbio-sistemakohiru zelula mota ezberdin garatzeko gai dira: astrozitoak, oligodendrozitoak eta neuronak ${ }^{2,3}$ (5. irudia).

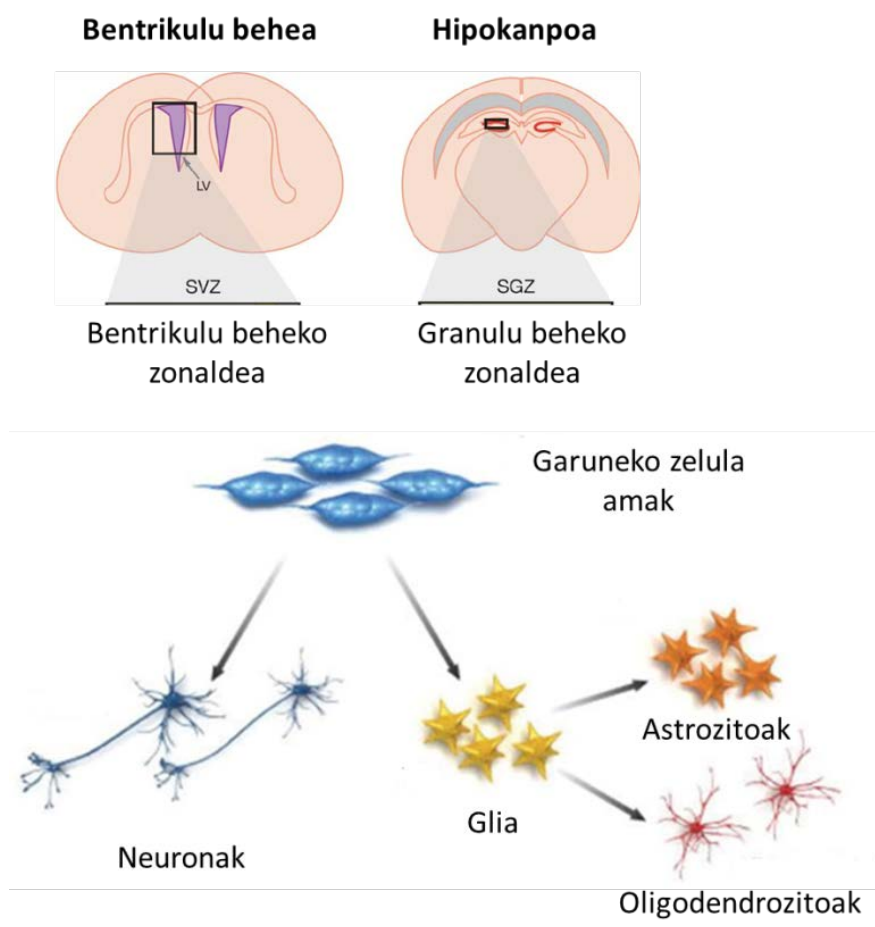

5.irudia: Arratoien zelula amen garuneko kokapena. Batez ere, bentrikulu azpiko eremuan (SVZ) eta hipokanpoko granulu azpiko eremuan (SGZ) kokatzen dira. Hauek desberdintzen direnean, garuneko zelula mota nagusienak sortzen dituzte, hala nola, astrozitoak, oligodendrozitoak eta neuronak. Arg. Egileak.

\section{Bentrikulu azpiko eremua (SVZ)}

Bentrikulu azpiko eremutik eraturiko neurona berriak estuki loturik daude usaimenaren zentzumenarekin, hori dela eta, karraskarietan ikertu da batez ere. Zonalde honetan zelula mota ezberdinak aurki ditzakegu: zelula amak B1 motako zelula bezala identifikatzen dira, egoera fisiologikoan lokarturik aurkitzen direlarik. Estimulu baten aurrean behin aktibaturik, desberdintze prozesuari esker, garatu gabeko aitzindariak ( $\mathrm{C}$ motako zelulak) sortzen dituzte. Hauek, bi edo hiru bikoizketaren ostean, neuroblastoak edo neurona aitzindariak (A motako zelulak) eratuko dituzte. Azken hauek izango dira neurona helduak emango dituzten zelulake 5 . Hauetariko bakoitza markatzaile espezifikoen bitartez desberdindu dezakegu (6.irudia). 


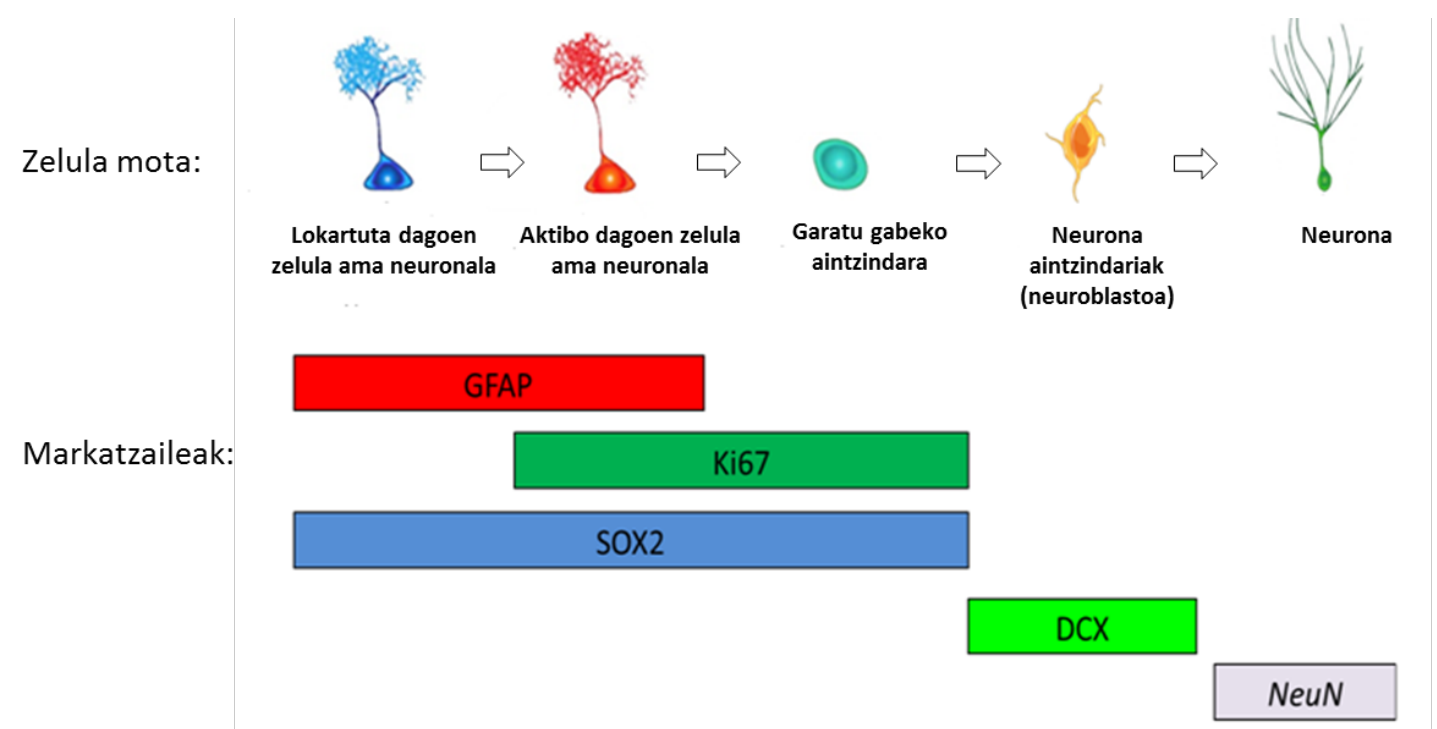

6.irudia: Sagu heldu baten garuneko bentrikulu azpiko eskualdean gertatzen den neurogenesiaren adierazpen eskematikoa. Markatzaile ezberdinak erabiltzen dira zelula mota ezberdinak identifikatzeko. Ingelesetik: GFAP (Glial fibrillary acidic protein), Ki67 proteina (proliferazioaren adierazle), SOX2 (Sex determining region Y-box 2), DCX (doblecortin) eta NeuN (Neuronal nuclear antigen). Hau honela, markatzaile ezberdin hauen konbinazioak detektatzean zelula mota ezagutzea baimentzen digu. Arg. Egileak.

\section{Hipokanpoko granulu azpiko eremua (SGZ)}

Neurogenesia ematen den bigarren eremu hau ikasteko gaitasunarekin eta oroimenarekin erlazionatzen da batez ere. Gauzak horrela, karraskarietan eginiko ikerketa guztiez gain, gizakietan ere nabarmenki aztertu da.

Granulu azpiko eremuan, erradial glia bezalako zelula amak edo 1 motako zelula bezala ezagutzen diren zelulak egoera ez-aktibo batean aurkitzen dira. Estimulu bati erantzunez bitarteko zelula amak edo 2 motako zelulak eratzeko gaitasuna dute. Aitzindari hauek ugaritu egiten dira neuroblasto zelulak edo 3 motako zelulak sortu aurretik eta hauek dira garatu gabeko neuronak sortuko dituztenak, garunean zehar migratuko dutelarik ${ }^{6}$.

\section{Zahartzea eta neurogenesi prozesua}

Ikertzaile guztiek onartzen dute neurona berrien sortze prozesu hau izugarri aktiboa dela enbrioi-garaian. Argi dago neurogenesia etapa helduetan ere ematen dela karraskari guztietan, baina gizakiaren kasuan oraindik ere argitzeko dago hipokanpoko neurogenesia noiz arte gerta 
daitekeen. Zein adin arte sortzen dira neurona, astrozito edo oligodendrozito berriak? Posible litzateke kalte baten ostean zelula amek zelula berriak garatzea?

Azken ikerketen arabera, egoera fisiologiko batean neurogenesia 7-13 urte bitartean gertatzen da, baina ez 18-77 urte bitartean, adin tarte honetan neurona berriak sortzea ezinezkoa izango litzatekeelarik ${ }^{7}$. Ikerketa honi kontra eginez, beste talde baten ikerketen emaitzek prozesu hau 65 urtetik gorako gizaki osasuntsuetan gertatu daitekeela egiaztatzen dute ${ }^{8}$. Izan ere, bitarteko aitzindariak diren zelulak, garatu gabeko neurona, glia eta garatutako neurona granularren kopurua antzekoa dela baieztatzen dute 14 eta 79 urte bitarteko gizabanakoetan. Gauzak horrela, ez dago argi gizaki helduetan neurona berriak noiz arte sor daitezkeen eta kaltetu edo galdu diren zelulak birsortu edo ordezkatu litezkeen. Urte batzuk itxaron beharko ditugu zalantza hauek guztiak argitzeko.

\section{Zeintzuk izan daitezke hurrengo pausoak?}

Beraz, zelula amak zahartzaroan gertatzen diren gainbehera kognitiboan duten garrantzia agerikoa da eta ondorioz, zelula hauek mantentzeko beharrezkoak diren mekanismoak ezagutzearen premia dugu. Ikerketa ezberdinek zelula amen agortzea modu aktiboan erregulatzen duten bidezidor molekular independenteak identifikatu dituzte. Hauen artean, Cdkn1a geneak (p21 bezala ezaguna) zelula amen agortzea eragiten duen molekulen produkzioa itotzen duela ikusi da, agortze zelularra ekidinez (erreferentzia). Beste ikerketa batzuek autofagiarekin, hau da, zelularen osagaiak desegiteko eta berrerabiltzeko prozesuarekin, erlazionaturiko geneak zelula ama neuronalen erregulazioan duten eragina azpimarratzen dute ${ }^{9}$.

Bestalde, P38 mitogenoa den proteina kinasa (p38MAPK) barne eta kanpoko estres egoeren oso sentsore garrantzitsua da eta zelulen homeostasiarekin erlazionaturiko prozesu ezberdinak kontrolatzen ditu, hala nola, zelulen ugaritzea, heriotza, zelulen berriztapena eta desberdintzapena ${ }^{10}$. Gainera, p38MAPK-ren aktibazioak zelula hematopoietikoen, muskulu zelulen eta gibel zelula amen agortzea eragiten dutela uste $\mathrm{da}^{10}$.Garunean zehazki, p38MAPK seinalearen aktibazioak garapen enbrionarioan eta jaio ondorengo aldian NSC-en erregulazioan garrantzi handia duela ikusi da. Tamalez, oraindik ez dira sakonki aztertu P38MAPK-ak NSCen funtzioan dituen ondorio positibo edo negatiboak ${ }^{10}$. Gure taldearen azken ikerketen arabera, p38MAPK aktibitatea handitua dago animali zahartuen bentrikulu azpiko eremuan eta baita 
animali hauetatik kultibatutako neuroesferetan (kultibaturiko garuneko zelula amak). Gainera p38MAPK farmakologikoki neuroesferetan inhibitu ondoren, neuroesfera hauek gazteagotu egiten zirela deskribatu da ${ }^{11}$. Emaitza hauek p38MAPKak garuneko zelula amen zahartzaroko barne erregulatzaile bezala duen garrantzia azpimarratzen dute.

Azkenik, Sox2 (sex determining region Y-box 2) transkripzio faktoreak ere zelula amen zahartze prozesuan garrantzi handia duela ikusi da. Gene honen adierazpena erregulatu gabe aurkitzen da zahartzaroarekin erlazionaturiko gaixotasun kronikoetan baina bere inplikazioa zahartze osasuntsuan ezezaguna izan da orain $a^{12}{ }^{12}$. Honen adierazpenean murrizpen esanguratsu bat ikusi da gizaki zein karraskarien ehun ezberdinak ikertzean, Sox2-ren murrizketa zahartzaroaren biomarkatzaile bezala erabili daitekeela ondorioztatuz. Hala ere, gizakian transkripzio faktore honen murrizketak duen efektua ezezaguna da oraindik. Azken urteetan, gure ikerketa taldea Sox2-ak zahartzaroan duen garrantzia aztertzen egon da. Genetikoki eraldaturiko saguak, Sox2 genearen dosi erdia dutenak, ikusmen murriztua daukatela deskribatu dugu, hots, transkripzio faktore honek informazio bisualaren fluxua baimentzen du. Datu hauek Sox2-ren adierazpena adinari loturiko ikusmen galerarekin inplikaturik egon daitekeela iradokitzen dute. Gainera sagu zaharretan eragindako Sox2 genearen murrizketak galera kognitiboa dakarrela ikusi da ${ }^{13}$, eta beraz, gene honen mantentzeak izan dezakeen garrantzia goraipatu nahi dugu.

\section{Ondorioa}

Azaldutako guztiarekin zelula amak zahartzaroan garrantzi handia dutela baieztatzeaz gain, garuneko zelula amen garrantzia ere egiaztatu da. Ondorioz, zahartzaroak eragindako garuneko zelula ama hauen agortzeak dakartzan ondorio kognitiboak ekidin edo leundu ahal izateko, eta baita, ondorio hauek osasun sisteman duten eragin ekonomikoa murriztu ahal izateko, garuneko zelula amen funtzioa ezagutu eta zelula hauen mantenu egokia baimentzen duten faktore ezberdinak identifikatzea oso garrantzitsua izango da etorkizunean.

\section{Bibliografia}

1. Barbi, E., Lagona, F., Marsili, M., Vaupel, J.W. eta Wachter, K.W. 2018. The plateau of human mortality: Demography of longevity pioneers. Science, 360, 1459-1461.

2. Dong, X., Milholland, B. eta Vijg, J. 2016. Evidence for a limit to human lifespan. Nature. 538, 257-259.

3. Lopez-Otin, C., Blasco, M.A., Partridge, L., Serrano, M. eta Kroemer, G. 2013. The hallmarks of aging. Cell, 153, 1194-1217. 
4. Bishop, N.A., Lu, T. eta Yankner, B.A. 2010. Neural mechanisms of ageing and cognitive decline. Nature. 464, 529-535.

5. Doetsch, F., Garcia-Verdugo, J.M. eta Alvarez-Buylla, A. 1997. Cellular composition and threedimensional organization of the subventricular germinal zone in the adult mammalian brain. J Neurosci, 17, 5046-5061.

6. Seri, B., Garcia-Verdugo, J.M., McEwen, B.S. eta Alvarez-Buylla, A. 2001. Astrocytes give rise to new neurons in the adult mammalian hippocampus. J Neurosci, 21, 7153-7160.

7. Sorrells, S.F., $\quad$ Paredes, M.F. , Cebrian-Silla, A., Sandoval K, Qi D., Kelley, K.W., James D., Mayer S., Chang J., Auguste I., Chang E.F., Gutierrez A.J., Kriegstein A.R., Mathern G.W., Oldham M.C., Huang E.J., Garcia-Verdugo M., Yang Z., Alvarez-Buylla A. 2018. Human hippocampal neurogenesis drops sharply in children to undetectable levels in adults. Nature, 555, 377-381.

8. Boldrini, B., Fulmore, C.A., Tartt, A.N., Simeon, L.R., Pavlova, I., Poposka, V., Rosoklija, B.G., Stankov, A., Arango, V., Dwork, A.J., Hen, R., Mann, J.J. 2018. Human Hippocampal Neurogenesis Persists throughout Aging. Cell Stem Cell, 22, 589-599 e585.

9. $\quad$ Casares-Crespo, L., Calatayud-Baselga, I., Garcia-Corzo, L., eta Mira, H. 2018.On the Role of Basal Autophagy in Adult Neural Stem Cells and Neurogenesis. Front Cell Neurosci, 12, 339.

10. Cuadrado, A., eta Nebreda, A.R. 2010. Mechanisms and functions of p38 MAPK signalling. Biochem J, 429, 403-17.

11. Moreno-Jiménez, E.P., Terreros-Roncal, J., Flor-García, M., Rábano, A., Llorens-Martín, M. 2021. Evidences for Adult Hippocampal Neurogenesis in Humans. J Neurosci. 41(12), 2541-2553

12. Carrasco-Garcia, E., Moreno-Cugnon L., Garcia I., Borras C., Revuelta M ., Izeta A., Lopez-Lluch G., de Pancorbo M.M., Vergara I., Vina J., Matheu A. 2018.SOX2 expression diminishes with ageing in several tissues in mice and humans. Mech Ageing Dev.

13. Moreno-Cugnon, L., Anasagasti, A., Ezquerra-Inchausti, M., Izeta, A., de la Villa, P., RuizEderra, J., eta Matheu, A. 2018. SOX2 haploinsufficiency promotes impaired vision at advanced age. Oncotarget, 9, 36684-36692. 